\title{
The Bugis Chronicle of Bone: English text
}

This work tells of the land of Bone and the ruling of Bone. All that there is now for hearing is what the old men tell.

May my belly not swell, ${ }^{1}$ may I not weaken, I will not part (from life), telling the names of the monarchs. A sun-shield extends a shadow over children of the splendid ones. ${ }^{2}$ Thus I seek approval before going on to set out in order the lineage of the ruling sovereigns.

There were kings, so the story goes, back in (the age of I La) Galigo, ${ }^{3}$ but then no longer was there anyone called king. For the people did not know how to discuss things with each other. The people just ate each other like fish do. They were selling each other all the time (as slaves). There was no longer customary order, let alone what might be called law. It is said that for the space of seven generations there was no king. ${ }^{4}$ For this same time also the people did not know how to discuss things with each other, nowhere was there customary order, nowhere law.

\footnotetext{
1 This is a standard formula that occurs repeatedly to excuse the author for using the personal name of high-status individuals. Here it heads a list of similar phrases in a general deflection of ill consequence.

2 The protection of a sun-shield or umbrella is a mark of nobility or high status. All those of appropriate descent share in this benefit according to their level of status. The exculpatory phrases can be taken to apply at all levels of status.

3 Refer to the commentary in the Introduction for discussion of La Galigo and other themes in this paragraph.

4 The figure of seven generations is probably conventional, for whatever reason, rather than literal.
} 
This, then, is how there began to be kings. It happened one day that the lightning and thunder raged together, ${ }^{5}$ the land also shook, it is said to have continued like this for one week. ${ }^{6}$ When the lightning, thunder and the earthquake had ceased, suddenly there was a man to be seen in the middle of the field. He was all in white. So it came about that the people gathered together, each according to his area. Then it was agreed by all the people to call him tomanurung. ${ }^{7}$ So it came about that all the people were of one view. Then they agreed to go together to attach themselves to this man whom they called tomanurung. They went there. The common people said, 'Here we have come to you, blessed one. ${ }^{8}$ Have mercy on us children. Do not disappear. You have settled in your land. You have us as slaves. Your wish is what we wish. Whatever the orders, we will execute them. Even our children and our wives, (if) you reject them, we also reject them in turn. If you stay here, then we will make you lord.'

After that, this man who was called tomanurung said, 'That is good, friends. I just say this to you. I am not able to be king, since I am but a slave. But if you wish to have a lord, there is my lord. You make him lord if you want to.'

All the people said, 'How do we know how we make lord someone we do not see?'

He who was called tomanurung said, 'If you really want it, I will show him to you.'

All the people said, 'That is indeed our wish. Be faithful in your mercy and in showing us the way.'

Following that, all the people were shown the way to what is called Matajang. Again thunder and lightning raged together when they reached Matajang. They came and saw the tomanurung sitting on the flat stone. He was all in yellow. Sitting together with the person of the king, there was one holding his umbrella, a yellow umbrella, ${ }^{9}$ one fanned him, one carried his sirih box.

5 Literally, they ate each other.

6 That is, for seven days. The figure of seven is again probably significant.

7 Tomanurung means, literally, 'descended one'- that is, a person who has come down from the upper world. See Section 7 of the Introduction for further discussion.

8 This phrase is in the form of a masculine personal name with the preceding La.

9 The yellow umbrella is a sign of royalty. 
When they came there to the tomanurung, the tomanurung said, 'There you are, old man. ${ }^{10}$

The old man said, 'Yes, lord.'

After that, all the people knew that the man who had been called king was nothing more than an old man. He who had been called tomanurung said, 'Again, I acknowledge my lord.'

Following that, all the people went to the tomanurung all in yellow. All the people said, 'Here we come to you, lord. ${ }^{11}$ We want you to have mercy (on us), and to establish yourself here in your land. Do not disappear. You we will make lord. Your wish is what we wish, just as commands are. Even our children and wives, (if) you reject them, we also reject them in turn. If only you will stay here, then you will have us as slaves. You will protect us against lack of food. ${ }^{12}$

The tomanurung said, 'Your thoughts are not double. You do not lie.'

Following that, all the people approved the words of the tomanurung. The (to) manurung was led back to Bone. Then that (to) manurung ruled in Bone, and a royal hall was set up. The royal hall was completed and the (to)manurung was taken up to sit in the royal hall. For that (to)manurung no report is heard about his personal name. Only for his deeds is he given a title. If he saw the plain full of people, he looked down on them and he just knew immediately how many people there were. Thus he was just given the title, may my belly not swell, Matasilompo'é <the Eye of the whole plain $>.^{13}$

Matasilompo'é married in Toro' with the (to)manurung of Toro', may my belly not swell. Their children were La Ummasa', may my belly not swell, and someone called, may I not be parted (from life), La Pattanrawanua ${ }^{14}$

10 'Old man' is a literal translation. The word also has connotations of political and social rank.

11 In this speech, which closely follows that addressed to the earlier figure, the honorific second person is used (except where it might cause confusion with the exclusive first-person plural). The contrast between the ordinary second-person forms in the previous speech and the honorific here is undoubtedly intentional.

12 The full sense is: 'You will be our protection against the small birds [dongi'] that infest rice fields, so that we are not left with empty ears of paddy.'

13 The sense of this name may be that he was able to see the whole of the area under his control. This implies that Bone was still very limited in extent.

14 Despite the masculine $L a$, this is certainly a daughter, as shown by her later marriage. This use of $L a$ is not as anomalous in a title-as this name seems to be-as it would be in a personal name. 
$<$ Marker out of territory>, by name. There were five in their family. As for the other names, they remain in records which are rolled up. ${ }^{15}$ This work only tells of the succession of events in Bone in their proper order.

As for the works of the (to)manurung who ruled in Bone, he first set up what is called bridge breaking. He regularised the exchange of goods for both parties. The person who has possession of goods, they all definitely belong together to the person. It is in good faith that they are held and there is no consequent litigation. He also set up precedents, laws and customary order. They were then followed. This (to) manurung also owned the Woromporong banner. ${ }^{16}$

When he had completed four eight-year cycles ${ }^{17}$ of ruling Bone he gathered together the people of Bone and took leave of them, saying, 'Sit down, friends. Do not wriggle about. This is my child called La Ummasa'. He succeeds me. By him also, I uphold our agreement.'

Following that, there was lightning and there was thunder. Suddenly, the (to) manurung, both husband and wife, were no more to be seen in their places. Furthermore it was seen that both the yellow umbrella was no longer to be seen in its keeping place, and the betel box was no more. Only then too was our lord, ${ }^{18} \mathrm{La}$ Ummasa', by name, may my belly not swell, immediately set up to rule. Also there was no longer an umbrella in Bone.

\section{2}

The (to)manurung of Matajang begat La Ummasa', also called To Mulaiépanreng $<\mathrm{He}$ who first had a grave $>$. After the disappearance of our lords, both husband and wife, La Ummasa', may my belly not swell, ruled in Bone. Only when he passed on was he called To Mulaiépanreng. When he ruled, only his shield shaded him. If he went forth, he just had

15 This is an important reference to the thin palm-leaf strips coiled up on a device somewhat like a modern cassette recorder tape, which were used for writing before the introduction of paper. See Macknight (2016).

16 This name refers to a cluster, understood as a cluster of stars - that is, the Pleiades.

17 A pariama cycle may also run for 12 or 100 years.

18 The first-person possessive, though in singular form in the Bugis, is clearly meant in the plural, as elsewhere in the text. 
to go in the sun, for there was no longer an umbrella in Bone. Also he was called Panrébessié <the Ironsmith>. He was also praised for his memory. He was also said to be vigilant. He was also said to be well-balanced.

The sister of ArumPone called $<$ La $>$ Pattanrawanua married the man who was king of Palakka, called La Pattikeng.

Also when (La Ummasa') ruled in Bone, he conquered Biru, he conquered Cellu, he conquered Malloi', he conquered Anrobiring, he conquered Majang. He also quarrelled with his brother-in-law, who was king of Palakka, called La Pattikeng. From both sides there arose a war between the brothers-in-law. After three months of war, neither had been beaten, and they were reconciled with each other. (La Ummasa') too was said to be without match in Bone in his authority, his eminence and his power. ${ }^{19}$

He had no child as heir, although he did, in fact, father To Suallé and To Salawaka, but their mother was only a commoner. When he knew his sister who had married in Palakka to be pregnant, he went to sleep on the problem and it is said he was shown what to do. After that he was relaxed at heart for he knew his sister, who was married in Palakka, was in labour. He called To Suallé and To Salawaka and said, 'Go now quickly westwards to Palakka for my young sister is said to be in labour. If my young sister is delivered, just take the baby in a rough sling, ${ }^{20}$ you hold it close, you bring it quickly eastwards to here. Thus its umbilical cord will be cut here, and thus too it will be washed here.'

To Suallé and To Salawaka did indeed hasten and went quickly. They came to Palakka, they went straight on up to the palace. To Suallé and To Salawaka did not even sit down. The wife of the king of Palakka was delivered and her child was a boy. His hair all stood up on end. To Suallé went straight up and took the baby in a rough sling, he held it close in a gathered-up sarong, then he went off eastwards to Bone. But the king of Palakka was absent when his child was taken.

19 These three attributes could also be taken in a purely physical sense to refer to his size, his height and his strength, but the context favours the political connotations.

20 The specific term, apopang, refers to a device formed from a folded areca palm leaf. For an illustration, see Matthes (1874b: Plate 15, Item 40). 
When they came to Bone, they went straight on up to the royal hall. After that (the baby's) umbilical cord was cut, and after that also, he was washed. ArumPone's sister, called I Samateppa ${ }^{21}$ was ordered to take care of him. I Samateppa looked after her nephew. That very night a general summons was given to the people of Bone, namely, 'Gather yourselves together tomorrow, bringing arms.'

Early the next morning, there were the people of Bone complete with arms. The Woromporong was unfurled. ArumPone went down to the meeting house. ArumPone said, 'For this, have I gathered together all you people of Bone. Here is my child called La Saliwu and entitled Kerrampélua'. To him I hand over the kingship of Bone. By this child of mine also, I uphold the treaty which our lord, before disappearing, entrusted to my hands.'

The people of Bone all gave their assent and after that they rendered fealty and the command was also given to send for the shamans. ${ }^{22}$ Immediately, on that very day, the ceremony was set in train. Our lord Kerrampélua' was enthroned by his uncle over seven days and seven nights. Indeed, the person who was holding the baby, so the story goes, was kept awake for seven days and seven nights. When the rites were completed, after that his umbilical cord was carried around the house. When his afterbirth had been carried around the house, our lord, the old one, moved down from the palace. ${ }^{23}$

Our lord Kerrampélua' was called ArumPone. He then lived in the royal hall. His aunt, called I Samateppa, acted as parent to him. Then our lord, the old one, if it happened he wanted to travel, he sent up to his child, saying, 'Go up to your lord. Say it happens that the lord of you (messengers) ${ }^{24}$ wants to travel. Give orders to take him.'

21 I Samateppa is not listed among the siblings of La Ummasa' in the other sources referred to in the previous chapter. It is easy to imagine the task of wet nurse being given to a woman of lower status.

22 The shamans or bissu are associated with all major traditional ceremonies in Bugis society.

23 Compare the modern Toraja birth ritual as described by Volkman (1985: 50) and Nooy-Palm (1986: 111).

24 That is, La Ummasa'. The use of the possessive covering the first-person plural inclusive and the second-person polite distinguishes this from the normal second-person possessive of the previous sentence. 
Then also the holder of the baby, so the story goes, would say, 'Go friends, you call people to go and carry your lord.' This was, so the story goes, how our lord organised it if it happened that he travelled, everything in fact was organised by our lord, the old one.

Seventeen years after he handed over kingship to his nephew, a serious illness struck our lord, the old one, and that carried him off. Then indeed he was called Puatta Mulaiépanreng <Our lord who first had a grave>.

\section{3}

Puatta’ Mulaiépanreng had as nephew our lord Kerrampélua'. Then our lord Kerrampélua' ruled in Bone. He was already king in the lifetime of his uncle, since on the night of his birth kingship in Bone was handed over to him. At his birth he was enthroned and To Suallé supported him and To Salawaka acted as chancellor. But if there was a legal judgement that was difficult for the judge to decide, it was sent up to the royal hall, and the discussion proceeded in this way. To Sualle held the baby and the people on both sides put their case. To Salawaka sorted out the arguments on both sides. Then the person who was holding the baby, he determined the penalty for the person, that is the person at fault. Yet this decision too was called the judgement of the baby.

When Kerrampélua' had grown up and come of age with women, then he went to Palakka to meet his real parents. As soon as they met when he came to Palakka, he was received by his real parents and was made their heir, and moreover he inherited the market of Palakka. The market of Palakka was brought to Bone and so the people of Bone had a market.

When he went to Palakka to meet his real parents, his marriage was arranged with his first cousin, called Wé Tenriroppo, the daughter and heir of the king of Paccing. They begat, may my belly not swell, (a child) called Wé Benrigau' and entitled Daéng Maroa. As well, she was called Makkalempié. She was also called Bissu riLalempili' $<$ Shaman at court $>.^{25}$ She was made queen of Majang. A part of the people of Bukaka were set apart and they were taken to live at Majang and they too were made to be

25 This name may only mean something like 'the Beauty in the royal household', rather than its literal sense. 
the people of Makkalempié. A long mansion was erected in Bone and it was called Lawélareng and Makkalempié was also given the name Puatta' riLawélareng < Our lady in La Wélareng>.

Our lord Kerrampélua' was praised as skilful, he was also praised as vigilant, he was also praised as diligent in agriculture, he was also praised as liberal-minded, yet he was not said to be especially clever, none could surpass his bravery for, as the story goes, from his birth fear never affected him and in his age, it is said, he never knew the sensation called fear. Hence he had the name Passoddo' Wakkaé <the Prod of enemies>.

Also he was the first king to give orders to pronounce curses to drive back the enemy if he wanted to raise the war against the enemy, for they are what are called Tuppu-batu <Standing on rock $>{ }^{26}$ but the earlier kings who went back to (La) Galigo had already organised (the conduct of) negotiations as well as of giving orders.

When Kerrampélua' was king, he created two red standards. ${ }^{27}$ That is there were the red (standards), two (of them) and the Woromporong, one on its left, one on its right. The people of Bone then divided themselves into three sections. The red (standards) shaded one section (each), the Woromporong shaded one section. It was the Woromporong that shaded the people of Majang and the people of Mata-Anging and the people of Bukaka-Tengnga and the people of Kawerrang and the people of Palléngoreng and the people of Mallari, and the headman of Matajang carried (the standard). It was the red (standard) on the right of the Woromporong that shaded the people of Paccing and the people of Tanété and the people of Lémo-Lémo and the people of Masallé and the people of Macégé and the people of Bélawa, and Kajao ${ }^{28}$ Ciung carried (the standard). It was the red (standard) on the left of the Woromporong that shaded the people of Araseng and the people of Ujung and the people of Poncéng and the people of Ta' and the people of Katumpi' and the people of Padaccengnga and the people of Madello', and Kajao Araseng carried (the standard). ArumPone in person was everywhere at all times, ArumPone gave instructions.

26 That is, the curses are made with the full confidence of someone who is, as it were, standing on rock-that is, a noble.

27 Le Roux (1930: 45, and Plate 2) describes and illustrates these.

28 Kajao means, literally, old man or, in modern Bugis, old woman. 
Our lord Kerrampélua' conquered Palléngoreng, Sinri, Anrobiring. He also conquered Lémpang, Mellé. He also conquered Sancénreng, Cirowali, Apala, Bakke', Tanété, Attassalo, Soga, Lampoko, Lémoape', Bulu'-Riattassalo, Parippung, Lompu.

When he was ruling too, he made one people of the people of Bone and the people of Palakka. The land of Palakka was adopted ${ }^{29}$ by Bone. Then it happened that the Limampanua-Rilauale' <Five territories east of the forest $>$ came to merge their land with Bone. Then it also happened that the king of Babauaé, called La Tenriwasu, met his grandson-in-law and made his land merge <with Bone>. ArumPone made one people of the people of Bone and the people of Babauaé. The land of Babauaé was adopted by Bone. Furthermore, it happened that the king of Barebbo came to make his land merge with Bone. The land of Barebbo was adopted by Bone. Then it also happened that the king of Pattiro, called La Paworong, came to meet ArumPone, for they were brothers-in-law, and made his land merge <with Bone>. Then the land of Pattiro was established as a vassal of Bone. Then it also happened that Cinennung, Ureng, Pasémpe' came to merge their lands <with Bone> and the three areas were established $<$ as dependencies $>$.

Also it happened that the king of Kaju, called La Tenribali, made his land merge with Bone and Kaju was established as a vassal. The king of Kaju too sent an envoy to ask in marriage the child of ArumPone, entitled Makkalempié, may my belly not swell, Wé Benrigau' was her personal name. The king of Kaju was accepted by ArumPone, and after that $<$ the envoy> returned to the territory of the king of Kaju, and so when he had come to his <king's $>$ territory, afterwards the groom proceeded to Bone. Arung Kaju, who was called La Tenribali, wed the child of ArumPone, who was entitled Makkalempié.

Then it also happened that Arung Ponré merged his land with Bone. Then also it happened that all the nine standard $s^{30}$ south of the forest and all the nine standards north of the forest came to merge their land with Bone. The nine standards south of the forest and the nine standards north of the forest were adopted by Bone. When Kerrampélua' ruled in Bone he conquered the area surrounding Bone.

\footnotetext{
29 Literally, 'was child to'.

30 'Standard' is used here to mean a village or territory. The usage draws attention to the importance for the ruler of military forces.
} 
Also that king is said to have greatly respected his parents. Also when that king was ruling he sent out his personal slaves and put them at Panyula' and they were called the people of Panyula'. Then, the slaves who came into his possession while he was king, he put those at Lipenno. Then the people of Panyula' and the people of Lipenno rendered a tribute of fish. Also they paddled if ArumPone went sailing. Also they acted as bearers if ArumPone went travelling.

When 72 years of ruling were completed, he gathered together the people of Bone with the vassals, and ArumPone said, 'This is why, people, I have gathered you together. I am old, and I feel my body to be weak as well. But I want to see you on parade. ${ }^{31}$

Following that, the people of Bone gave their assent and the people agreed too on a day. When the appointed day came, the people paraded, the Woromporong was unfurled. After the people had paraded, (ArumPone) received as guests the people of Bone with the vassals. After the people had eaten, ArumPone said, 'Just one thing more, people, I want to announce to you people of Bone. This, my child called Wé Benrigau' I wish to rule in Bone, if I die. To her hands also I entrust the treaty which Puatta Mulaiépanreng enjoined me (to hand on).'

Following that, the people went home. Only one night after he had made his will, illness struck him and he also departed (this life).

\section{4}

Our lord Kerrampélua' begat Mallajangngé riCina $<$ She who disappeared in Cina>. When our lord Kerrampélua' had passed on, then Makkalempié ruled in Bone. That had been in the will of her parents, and, may my belly not swell, Wé Benrigau' was her personal name and Daéng Maroa her title. She was also called the queen of Majang, and only when she ruled was she called ArumPone. She was praised as having intelligence.

Two years afterwards she had her menarche and it was thought best by her parents that she marry Arung Kaju, called La Tenribali. They had nine children, but only two are entered in this work. As for their (other)

31 Literally, in a state of preparation (presumably for war). 
seven children, they still remain in the records on strips (of palm leaf). ${ }^{32}$ But those of their children in this work are, may my belly not swell, called my lord La Tenrisukki' and La Tenrigora.

Makkalempié ruled and sent the king of Katumpi', in Attassalo, called La Dati', to ask about buying the hill of Cina for 90 buffalo bulls, and it was sold. Our lady Makkalempié bought the hill south of Laliddong, and she bought it for 30 buffaloes. Following that, she ordered people to settle on the hill of Cina. She also ordered them to lay out gardens. She also ordered people to go to the hill south of Laliddong which she had bought.

Then two years after they had laid out gardens on the hill of Cina and they had worked up the fields south of Laliddong, the agriculture and the gardens of those who lived at Cina were destroyed by the people of Katumpi'. ArumPone gave orders that the king of Katumpi' should call the past to mind. ${ }^{33}$

Only three months after the message of ArumPone that the king of Katumpi' should call the past to mind had been sent, the official of ArumPone was killed. (Bone) attacked Katumpi', and Katumpi' was conquered by the people of Bone, it was plundered on that very day, and the fields east of Laliddong and north of Laliddong were taken.

Then the youngest son of ArumPone, called La Tenrigora, he was given his inheritance in Majang and in Cina. Thus La Tenrigora was called Arung Cina, he was also called Arung Majang.

Then the child of ArumPone called La Tenrisukki', may my belly not swell and may I not part (from life), to him the kingship of Bone was handed over. He was enthroned by his parents, and called ArumPone, may my belly not swell, whose named was La Tenrisukki'. He was 11 years (old) ${ }^{34}$ when kingship was handed over to him by his parents.

Then after our lady Makkalempié had enthroned her child and established (him) in the royal hall, she just went to Cina to live with her youngest son, called La Tenrigora.

32 Compare this with the similar statement in Chapter 1 and the note there.

33 Presumably, he was being asked to remember that he had bought it on behalf of Bone.

34 Other versions of the chronicle say he was 19 years old. 
Makkalempié lived in Cina for four years. Then it happened one day that Makkalempié chanced just to go up to her attic and thereupon sat down in the attic on part of a loom. Then there was what the men of old call Fire God. It just chanced to be there turning hither and thither at the house, it followed the staircase, ${ }^{35}$ so the story goes. It came, so the story goes, up into the house turning hither and thither all the time, it even mounted up to the attic. Yet when the Fire God died out, then too Makkalempié was not to be seen. She was called Mallajangngé riCina.

5

Mallajangngé riCina begat Mappajungngé $<$ He who uses an umbrella $>$. La Tenrisukki', may my belly not swell, ruled in Bone. It was already four years after rule had been handed over by his parent when she who disappeared passed on. Then he married his first cousin called Wé Tenrisongké. They were the parents of, may my belly not swell, he who was called La Ulio and entitled Botéé <the Fat Man>.

All the kings of the hills together came to merge their land with Bone, and they were established as vassals.

Also when he ruled in Bone, it happened that the Datu of Luwu, entitled Dewaraja, attacked Bone. Then the Luwurese landed south of Cellu, and took up a position. Then afterwards there were skirmishes between the parties in the roads and part of the women escaped, and the people at Attassalo followed them. They went southwards towards Attassalo at the hour before dawn, when the Luwurese right there raised the war cry. (The Luwurese) wanted to follow up their cry. But also the people of Bone had settled into position at Biru. Just as the dawn of the day was breaking, the Luwurese spied (the people of Bone), then (the Luwurese) saw the women in the road east of Anrobiring. For these, (the Luwurese) charged ahead. The people of Attassalo struck at the Luwurese. The Luwurese were recognised by the people of Bone. The Luwurese were put to disorderly flight. The umbrella of the Datu of Luwu was captured. Yet the Datu of Luwu was not wounded. It just happened that ArumPone restrained the people, saying, 'Do not wound the person of the Datu of Luwu.' 
Then (the Datu of Luwu) was followed eastwards right up to his ship. There were only 20 reaching the ship of the Datu of Luwu. It was only a small ship that he got to and departed in. He sat in it and went to his territory. So from this, there was again an umbrella in Bone. It was actually a red umbrella, the umbrella of the Datu of Luwu that was captured. Hence La Tenrisukki', may my belly not swell, was entitled Mappajungngé.

Also when he was ruling in Bone, the people of Mampu and the people of Bone quarrelled. War broke out between them and they raised the war cry against each other, so that they clashed south of Itterrung. The people of Mampu were repulsed and made to go back to their territory. Then Arung Mampu went out and made obeisance, offering a thousandfold ransom. ${ }^{36}$ 'You may do anything, ArumPone, if only you do not send away (from me) my child and my wife.'

ArumPone said, 'I only send you home, Arung Mampu, you establish yourself as a vassal of Bone, you are not unimportant in Bone, you do not lack pure gold, long cloths, long possessions, for you to hand on to your descendants.'

After that Arung Mampu was sworn (to loyalty). After Arung Mampu and his retinue were sworn (to loyalty), ArumPone returned to his territory.

When he had ruled 27 years, an illness struck him. He assembled the people of Bone, saying, 'My illness is serious, but if I die, there is my child, called La Ulio, he will succeed me.' After he had made his will, then too the way to his burial was clear.

\section{6}

Mappajungngé begat Matinroé rItterrung $<$ He who sleeps in Itterrung $>{ }^{37}$ When Mappajungngé had passed on, Botéé in turn ruled in Bone since that had been willed by his parent, and, may my belly not swell, La Ulio was his personal name.

36 Matthes (1874a: 692) explains that the phrase sebbu kati does not mean 1,000 kati, but 8,888 reals, 88 duits. The repetition of the eight applies in various levels for different offences. A kati is a unit of monetary value, but the word is probably also associated with an alternative (and perhaps older) meaning of gold.

37 This is the first occurrence of the normal form of high-status necronym referring to the place or some other circumstance of the individual's death. 
It is said that while yet young, he was corpulent. His bearers were more than seven and his bearers were interchanging. Hence he was entitled Botéé.

As king he went on inspections and gave orders (for improvement). Also he was said to like cockfighting, and was said to be well-balanced.

Then Botée is said to have married the child of the king of Pattiro, entitled Magadingngé $<\mathrm{He}$ who wears armbands $>,{ }^{38}$ and she was called Wé Tenriwéa, and entitled Danraé. ${ }^{39}$

Botéé married the child of Magadingngé, and they bore, may my belly not swell, (a child) called La Tenrirawé and entitled Bongkangngé, ${ }^{40}$ they also bore, may my belly not swell, (a child) called La Icca'; they also bore, may my belly not swell, (a child) entitled Tenripauang; they also bore, may my belly not swell, (a child) called I Lémpe'.

This Botéé as king was the first to be attended by Kajao Laliddong. ${ }^{41}$ Also as king he made a treaty with the Karaeng of Gowa ${ }^{42}$ called Daéng Matanré. ${ }^{43}$ As well, the agreement is called Sitettongenna Sudeng La Téariduni <Sudang and La Téariduni standing together $>{ }^{44}$ Also he conquered the Datu of Luwu. When he stayed at Cénrana he was with the Karaeng called Daéng Bonto, ${ }^{45}$ the child of Daéng Matanré. The Karaeng took the contents, ArumPone took the stalk. ${ }^{46}$

Botéé was also married in Mampu to Wé Tenrigau', the child of Arung Mampu called Daéng Palimpu.

Also when Botéé was ruling in Bone, the Karaeng of Gowa came here and was the first (Karaeng of Gowa) to set foot on the land of Bone. Then it is said the Karaeng of Gowa and ArumPone conferred south of

38 This sense of the title is somewhat uncertain. Another possibility is 'the man the colour of ivory'.

39 On one reading, this could be Daraé, which means 'the Blood', but it is probably better to read Danraé and relate it to the old Bugis word denra, meaning a high-status woman.

40 The literal meaning of this title is uncertain.

41 This name, which literally means 'the old man of Laliddong', refers to the best-known sage or legal authority in Bugis customary law.

42 Karaeng is a Makasar title and is always applied to the ruler of the State of Gowa.

43 This is Tumapa'risi' Kallonna.

44 These are both famous swords in the regalia of the two courts. For La Téariduni, see Bakkers (1866: 190 , and Plate 1). Both items were removed to Batavia in the early twentieth century but were returned in the 1930s_La Téariduni to Watampone and Sudang to Sungguminasa, where they are still kept (Budiarti 2007).

45 This is Tunipalangga.

46 The word means, literally, the central rib of a leaf, such as a palm leaf. As Matthes has written in the manuscript, the sense means the ArumPone got the land and the Karaeng got what was in the land. 
Laccokkong ${ }^{47}$ on (the question of) the people of Gowa and the people of Bone killing each other. If a person of Bone struck the blow, the Karaeng of Gowa would wrap (the body) in a sarong, if a person of Gowa struck the blow, ArumPone would wrap (the body) in a sarong. ${ }^{48}$ Also while he was ruling, the Karaeng of Gowa was accompanied (by him). They took the thousandfold ransom ${ }^{49}$ from the people of Wajo at, so it is said, Topacceddo. ${ }^{50}$

When 25 years of ruling in Bone were completed, the people of Bone were gathered together, and he said, 'I want, people, to hand over the kingship to my child called La Tenrirawé.'

The people of Bone gave their assent, and his child was enthroned over seven days and seven nights. After his child was enthroned, our lord Botée went down from the palace. He divided his territory into two. There were those who went to Mampu to his wife, there were those who went to Bone.

Then Botéé was angry with his nephew, called La Paunru. He was angry too with his first cousin who was king of Paccing and called La Mulia. They wanted to entrust themselves to the people of Mampu and that pardon be sought. Then it chanced that Botéé went to spend the night (with his wife) in Mampu when the people of Mampu had not yet got the message to (him), and Botéé went down to cockfight. He saw his first cousin and his nephew. All over again he was newly angry. When he left to return again to Bone, La Paunru and La Mulia consulted together, 'It is good that we follow up the old man. We will entrust ourselves (to him) and so at least we will ask for pardon.'

When he reached Itterrung, Botéé turned to look back, and he saw his first cousin and his nephew, and he thought himself to be followed by them wanting to run amuck. He ordered his litter to be set down. So La Paunru felt himself to be deprived of his freedom and he just ran amuck slaying Botéé and himself together. I La Mulia slew another person as well. Botéé was called Matinroé rItterrung.

47 The name is known within the modern town of Watampone, but this seems an unlikely identification in the context.

48 The intention of these provisions was, presumably, to show their mutual respect and toleration.

49 See the note on the thousandfold ransom in the account of the previous reign.

50 Noorduyn (1955: 68) suggests this was in southern Wajo, on the Cenrana River. 


\section{7}

Matinroé rItterrung begat Matinroé riGucinna $<\mathrm{He}$ who sleeps in his urn>. Then Bongkangngé ruled for he had already been made king in the lifetime of his parent, and, may my belly not swell, La Tenrirawé was the personal name of Bongkangngé. Bongkangngé was his title. He was married in Timurung to the queen of Timurung, called Tenripakkiu, and there were two children. One called La Maggalatung, he died young. One called Punna riSompa, ${ }^{51}$ he was trained to succeed in Timurung, and died by a person running amuck. I Da Kalula was the name of the person who ran amuck.

Bongkangngé was, in fact, not known for being clever, yet he was praised as good-hearted, he was praised as a person who enjoyed entertainment, he was also praised as righteous, he was also praised as liberal-minded, he was also praised as a conqueror, he was also praised as liking duels to the death. He is also said to have liked family who were of lower status (than him), he is also said to have taken advice from his parents, but he is said to have been extremely angry if he were annoyed.

Also when he was ruling, he appointed people to act as officials and the officials were the heads of his nobility. (There was) a head for the territory, and for the young men of noble birth, ${ }^{52}$ and for all who were designated craftsmen, and also for all those women who acted as companions, ${ }^{53}$ for the bearers, for the wood-carriers, for the servants-in-waiting, for the (servants) who arranged the (court's) food, for the concubines. ${ }^{54}$

Also then there began to be guns.

When Bongkangngé was ruling, it happened that the Karaeng of Gowa entered Bone for cockfighting. Then a hundred katis $^{55}$ rested on the contest for the Karaeng, and ArumPone wagered the people of Panyula' with (its)

51 The meaning of this name seems to be the person to whom homage is paid, but there may be other possibilities.

52 Matthes (1872: Vol. 3, p. 69) has a note on the difficulty of translating the Bugis found in all of NBG 99, NBG 100 and NBG 101. We follow his general sense and look also to the equivalent ana'bura'ne in Makasar.

53 This phrase is obscure. It may mean they acted as wet nurses.

54 Matthes (1872: Vol. 3, p. 69) has a note on the difficulty of translating this. The translation as 'concubines' remains a guess.

55 A kati is here a unit of value. The phrase used does not necessarily mean exactly 100 of them. See Note 36. 
territory. The cock of the Karaeng was red, the cock of ArumPone was white with red on wings and breast. The cock of the Karaeng was killed, and the hundred katis also paid out.

Also while he was ruling, the people to the west of the wood decided to attach themselves to Bone. He conquered Awo, Téko, and he also conquered them all at Attassalo, which was an enemy for the second time.

Also when he was king, there were the Three Powers ${ }^{56}$ blocking the door to Gowa and they attached (themselves) to Bone and were established as vassals. Then the Karaeng entered (Bone) so that south of Méru the Makasars and the people of Bone clashed. They fought for seven days and after that the people conferred and the people of Bone and the people of Gowa were at peace with each other. They determined that the people of Bone went up to a boundary south of the River Tangka and running up to the high (country).

Also when Bongkangngé was ruling, the was a datu-ship ${ }^{57}$ acknowledged by homage in Sawitto, and (the datu) was driven out and came here to Bone.

Also when he was ruling, the people of Soppeng divided (themselves) within the territory. Arung Soppéng-Riaja, ${ }^{58}$ entitled Mabbélua'é $<$ He with the hair (on his head) >, was deprived of power and came here to Bone. When Mabbélua'é was thus in Bone he married the sister, called Tenripauang, of the king of Bone. She bore (a child) called I Dangke' and entitled Lébaé <the Monarch>. (The child) was also called the Datu of Mario. The sister of ArumPone called, may my belly not swell, Wé Lémpe' married the maddanreng ${ }^{59}$ called La Saliwu, and they were second cousins. They were the parents of, may my belly not swell, (a child) called La Tenrirua, whose name after death was Matinroé riBantaéng.

56 This is not the famous Tellumpoccoé or Three Power alliance of 1582, which is described below, but an earlier grouping of Bulo-Bulo, Lamatti and Raja - all south of Bone. In other sources, they are called Tellulimpoé or the Three Communities.

57 Datu is used as a term for the ruler in several states of the peninsula.

58 This means West Soppeng. It appears to be a mistake for Soppeng-Rilau or East Soppeng. This man is known in sources from Soppeng as La Makkarodda To Tenribali (Nur 2007: 61).

59 The maddanreng was one of the chief ministers of the court of Bone and was traditionally charged with business beyond the court. The name means, literally, 'He who is near (the ruler)'. 
Also while Matinroé riGucinna ${ }^{60}$ was ruling, it happened that the nephew of the Karaeng of Gowa, called Daéng Pabéta entered Bone. The nephew of the Karaeng was here in Bone and just afterwards met a person running amuck and was entitled by the people of Bone Daéng Patobo ${ }^{61}$ Daéng Patobo' was in Bone, and it happened that the Karaeng called Daéng Bonto ${ }^{62}$ attacked Bone, and thus they landed at Cellu. Then the people of Bone and the Makasars made war. Daéng Bonto was wounded with ipo poison. ${ }^{63}$ The people fought for five days. Then the Karaeng went back to his territory.

Two years after they made war at Cellu, it happened again that the Karaeng of Gowa attacked Bone. Thus on a large river ${ }^{64}$ (he) placed a fort and the people of Bone and the people of Gowa fought. Daéng Patobo' was wounded by a steel (lance). For more than seven days they fought. Then an illness struck the Karaeng and he had to return to his territory, and died within two months.

It happened again that the Karaeng Daéng Parukka ${ }^{65}$ attacked Bone. All the people west of the forest became enemies. As for the people of Timurung, they deserted their children and their wives, and came here eastwards to Bone, crowding themselves in. Only women, so the story goes, were said to be living in Timurung, together with their children. As for the five territories to the east, they brought the wives up to Cinennung, and the men entered Bone, crowding themselves in.

Since the people of AwamPoné ${ }^{66}$ were also enemies, the Karaeng placed a fort there at Pappolo. When his fort was finished, he advanced on Bone. He burnt half of Bukaka and Takké Ujung. When it was already afternoon, the Makasars wanted to drive away (the people), and they were recognised by the people of Bone. The Makasars were repulsed and the Karaeng was forced to flee as far as Cempaé, and the Makasars were almost all killed. The Karaeng was cut down. La Tunru' was the name of (the man) who cut him down.

60 The Bugis here and in the following section gives the name as Matinroé riGucié, or 'He who sleeps in an urn'. There is no significance in the variation.

61 This is a play on words. Pabéta means conqueror; Patobo' means a stabber (with a kris). This is the ruler of Gowa known as Tunijallo'.

62 That is, Tunipalangga.

63 There is a vast literature on the poison known as ipo or upas. For an introduction, see Yule and Burnell (1903: 952-9).

64 Probably the Walennae or the Great River that flows through the centre of the peninsula.

65 That is, Tunibatta.

66 That is, North Bone. 
There was only the Karaeng called Daéng Padulung ${ }^{67}$ and the people of Gowa looked (to him). The Karaeng of Tallo sent to Bone. The envoy of the Karaeng of Tallo announced, 'There were two lords of ours, one you have cut down on a mat, ${ }^{68}$ and one you have cut down in the centre of the field. But we have wished for what is good, we have not wished for what is bad.'

Kajao Laliddong said, 'Since that is what you say, tomorrow I will go out to the Karaeng.'

It was early the next morning when Kajao Laliddong went out. Then the Karaeng made a treaty and afterwards they agreed on its terms. After the Karaeng of Tallo, called Daéng Padulung, had made a treaty with the people of Bone, Daéng Patobo' was made king in turn in Gowa.

Also when that Bongkangngé was ruling in Bone, he quarrelled with the Datu of Luwu, called Sangkaria. Since again the Luwurese were unwilling to acknowledge Cenrana as territory (of Bone), yet again the Luwurese attacked Cenrana. Thus there were two occasions when the land of Cenrana was captured by the people of Bone at the point of the sword. Then the people of Unyi began to be slaves to Bone.

Also when Bongkangngé was ruling in Bone, he made friends with the Arung Matoa of Wajo called To Uddama, and he also made friends with the king of Soppeng, entitled Pollipué. ${ }^{69}$ When they were working together at Cenrana, they met to become brothers. Then they agreed to make each other brothers, saying, 'It is good to meet at Timurung and conclude our discussion when the moon is full.'

When the day that had been fixed came, they met in Timurung. There were all the people of Bone and their vassals, there were also all the people of Wajo and their vassals, and there were also all the people of Soppeng and their vassals. Then they placed a meeting house in Bone and then placed there a cockpit. When the new moon rose, the people of Bone, the people of Wajo and the people of Soppeng gathered together. ArumPone, the Arung Matoa of Wajo and the Datu of Soppeng sat down together and made those three lands brothers to each other. Indeed it also went as far as if they were brothers from the same mother and the same father, Bone the

67 That is, Tumenanga riMakkoayang of Tallo.

68 That is, by sickness.

69 In Soppeng sources, this is La Mappaleppe' Patola'é. See Nur (2007: 64-70). 
eldest, Wajo was the child in the middle, Soppeng was the youngest. After that they took an oath together. They swore that they would not diminish each other, that they would not envy each other's pure gold, long cloths and fine possessions. After that they buried stones, and called the lands Tellumpoccoé $<$ the Three Powers $>.^{70}$

That king was greatly liked by the people of Bone, and greatly cherished. Two years after burying the stones for Tellumpoccoé, an illness struck Bongkangngé. He gathered the people of Bone together. 'This, people, I announce to you, there is my younger brother to succeed me.'

He summoned his younger brother, called, may my belly not swell, La Icca'. He said, 'This I announce to you, that I am ill. Take care of your affairs for I intend that you should rule here if I should die. This also I announce to you, that if I die, there are no restrictions on making my funeral. I intend you to marry your sister-in-law. May you indeed be lucky and may you have a child by Arung Timurung. I intend that you marry. It is hard to find a woman with such quality and intelligence as she has. May you care for the land of Bone.'

After he had made his will, he died. He was called Matinroé riGucinna.

8

Matinroé riGucinna was the brother of Matinroé riAddénénna $<$ He who sleeps on his staircase>. When Matinroé riGucinna had passed on, may my belly not swell, then La Icca' was king in Bone since that was willed by his elder brother. After he had arranged the funeral of Matinroé riGucinna, he was enthroned.

After he was enthroned, he married the queen of Timurung, Tenripakkiu. They bore, may my belly not swell, (a child) called La Tenripale', entitled To Akkempéang. They also bore, may my belly not swell, Wé Tenrijello', and she was entitled Makkalaru'é, and also there was one who died while young.

70 This important treaty, which can be dated to 1582 , was frequently appealed to over the following centuries. The burial of the three stones, after a ceremony involving the breaking of eggs, symbolises the permanency of the treaty. The symbolism is discussed by Matthes (van den Brink 1943: 548) and the political situation by Noorduyn (1955: 85-6), who also lists various copies of a text of the treaty (p. 27) in the manuscripts available to Matthes and published by him (Matthes 1864: 532-6). See also Nur (2007: 66-8). 
When he who was called La Icca', may my belly not swell, was ruling in Bone, it happened that the Karaeng of Gowa attacked Bone. But he did not arrive and the Karaeng went back.

The thoughts of that king, may my belly not swell, are not known. Only the facts of what happened are entered in (this) work.

When he was ruling, the people of Bone began not to know how to discuss things with each other. He was angry at Arung Pallenna, called La Panaongi, and entitled To Pawawoi. Then (Arung Pallenna) was exiled as far as Sidenreng. When he was bored with staying in Sidenreng, he wanted only to come back to Bone and ask pardon. He was ordered to go away up to Buki'é. Arung Pallenna was followed and killed. The king of Paccing too was killed. The maddanreng of Palakka, called To SaliwuRiwawo, was also killed. Many noblemen of Bone were killed too. (La Icca') plundered people who should not be plundered. He promoted people who should not be promoted. The inability of the people of Bone to discuss things with each other increased, but still nothing was done.

This is how, so the story goes, the break was made. It happened one day that there was a man of Bone and (La Icca') went to deprive him of his wife, and when he got there, the man wanted to kill him. The man fled, and then (La Icca') just killed the man's wife. After that he put (the house) to the torch and the fire consumed half of Bone up to Matajang and came to the west of Macégé. The people of Bone scattered everywhere. Then what nobles there were took themselves off, and went south to Majang. Our lord of Majang said, 'Why are you here?'

The people of Bone said, 'We do not know how to tell of it, lord. Just look and you will see northwards the territory of Bone.'

When our lord of Majang looked, he struck his breast, and said, 'The change, the work of my lord (La Icca'), is distressing. But the people of Bone do not yet express our opinion. Send someone to get me my nephew called Da Malaka, from Mampu, for only he is an old nobleman. ${ }^{171}$

The people said, 'He is just north in Palakka, lord.'

He was sent for and brought. Before long, he was there. Da Malaka said, 'Why, lord, have you sent to get me?'

71 Literally, an old ruler. 
Our lord of Majang said, 'This is why you have come here. Do you not see the smoke and fire in Bone?'

Da Malaka said, 'It is clear, lord, I do see it.'

'That is why I sent to get you. What do you think about it?'

Da Malaka just remained silent. Yet three times the question was put by our lord of Majang, and after that (Da Malaka) said, 'I am afraid, lord, and it is as well if I am surrounded by no more than reproaches.'

Our lord of Majang said, 'We are both together in this. We share but one neck.'

Da Malaka said, 'Such is your word, lord, and there is no error (in it) which comes to mind. What you have expressed clears the honour of the land. Although our lords of former times have already made the land more honoured than their own persons, yet they have not laid down a customary procedure for driving out (a king). I, then, initiate this procedure. I will drive out my nephew.'

It happened that Da Malaka set up a statement. He sent (an envoy) to his nephew to say, 'Depart, you are not worthy of the land.'

The envoy arrived and there on the ground ${ }^{72}$ (La Icca') met and received the person who had been sent. Yet even before he had delivered all (his message), the envoy was killed, and after that (La Icca') put to the torch all the houses of Bone within the wall.

When our lord of Majang was informed that there was no longer a house within the wall, our lord of Majang said, 'Carry me, fellows, and bring (me) to Bone, and I will go to slay myself and my grandson. It is possible for me to oppose and kill him and myself, since he is no king.'

Da Malaka said, 'I will also go, for by now the opinion is secure that we share but one neck.'

All the people went to Bone. (La Icca'), all by himself, came to meet them there. When he saw the common people, he rushed straight at them and killed many people. The affair was like this, so the story goes. There were those he rushed straight at, and they fled. There were those behind him,

72 That is, not in a formal audience in the palace. 
and they pursued him, until he was exhausted. Then he went and leant on his staircase, and our lord of Majang split open the head of his grandson, and he died. Then he was called Matinroé riAddénénna. The people also say that he is the man who took his palace (with him). It was 11 years he ruled, and then he died.

\section{9}

Matinroé riAddénénna was first cousin to Matinroé riBettung $<$ He who sleeps in Bettung>. After the death of Matinroé riAddénénna, the people of Bone gathered together with our lord of Majang and consulted together. 'Whoever will we set up as king?'

Then the king of Majang proposed a plan. The king of Majang said, 'The only person who is in the category for you to take as king is my grandson La Pattawe', the child of Arung Pallenna, and grandson of Makkalempié.'

So it came about that the people of Bone agreed to give their allegiance (to him) and to give their assent. Arung Kaju was then established as king in Bone, and was called ArumPone. He was called La Pattawe'. Then ArumPone married the queen of Mampu. Their child, may my belly not swell, was called Tenritappu. ${ }^{73}$ Then La Tenrirua, may my belly not swell, married his first cousin called Dangke', and they were the parents of (a child), may my belly not swell, called La Tenrisui. ${ }^{74}$ But no tale from the time of his kingship is now to be heard. They merely say that he ruled for only seven years in Bone. He went to Bulukumpa, ${ }^{75}$ and there an illness struck him, and that also carried him off and he died.

\section{0}

Matinroé riBettung begat Matinroé riSidénréng <She who sleeps in Sidénréng>. Since she, called I Tenritappu, was the child of Matinroé riBettung, she was called ArumPone.

73 The name Wé Tenritappu also appears in many places as Wé Tenrituppu. Matthes (1872: Vol. 3, p. 73) is wrong in his note; she is not the same person as I Dangke'.

74 As correctly noted in Chapter 13, this was a daughter and her name was Wé Tenrisui.

75 The modern spelling is Bulukumba. 
When she was ruling, she established Arung Pitu <Seven Arungs $>.^{76}$ The headman of Tibojong was called Arung Tibojong. The headman of Ta' was called Arung Ta'. The headman of Ujung was called Arung Ujung. The headman of Poncéng was called Arung Poncéng. The headman of Tanété was called Arung Tanété. The headman of Macégé' was called Arung Macégé'. ArumPone said, 'For this, people, I have established you as Arung Pitu, I want you to look after the agriculture and the guests of the queen of Bone, since I am a woman, and I want you to seek the scattered contents of the palace. But I establish you as Arung Pitu not so that you might tread on the edge of the land of Bone, ${ }^{77}$ and not so that you might drive (people) to go away, and not so that you might bequeath things to your children without me knowing of it, unless, that is, we who are all descendants of Mappajungngé sit down together and agree together who is king (or queen) in Bone. Only after that go and after that also go forward with your bequests to your children and grandchildren.'

Also when she was ruling in Bone, it happened that the Karaeng of Gowa attacked in order to bring the Islamic faith, and he made Ajatappareng follow the war cry. Tellumpoccoé went to meet the Makasars. Hence the Karaeng went back to his own territory.

Only one year after, it happened that the Karaeng attacked PandangPandang, and again Tellumpoccoé went and they met each other east of Bulu' Sitompo', and the people threatened each other and Tellumpoccoé was repulsed. They went each to their own territory and the Tellumpoccoé alliance of Bone, Wajo and Soppeng was destroyed.

One year after Tellumpoccoé was destroyed, it again happened that the Karaeng attacked Soppeng. Then the people of Bone and the people of Wajo did not go to help the people of Soppeng. Soppeng was conquered and the people of Soppeng became Muslim.

One year after the confession of faith by the people of Soppeng, it again happened that the Karaeng attacked Wajo. The people of Wajo submitted and the confession of faith was again introduced.

76 This name was used for the Hadat or Council of Bone in later times. In the list of members given by Bakkers (1866: 70-1) and as noted by Matthes (1872: Vol. 3, p. 74), Tanété is divided into north and south areas, each with its own Arung, thus making up seven Arung in all.

77 This might mean they were not to rock the land of Bone like a boat or bring it to destruction, as Matthes suggests (1872: Vol. 3, p. 74). Alternatively, it might mean they were not to go near, or across, the borders of the kingdom. 
One year after the confession of faith by the people of Wajo, ArumPone went to Sidenreng wanting to inquire about the conditions of the Islamic faith. She arrived in Sidenreng and became Muslim. Also there in Sidenreng an illness struck her and carried her off. Nine years she ruled in Bone, then died, and was called Matinroé riSidénréng.

\section{1}

Matinroé riSidénréng was first cousin to Matinroé riBantaéng. When Matinroé riSidénréng passed on, the people of Bone gathered together. Then they agreed on Arung Palakka, and he was also king of Pattiro, since he was a grandson of Mappajungngé on both sides. Mappajungngé and Arung Palakka had an umbrella raised (over them). His personal name, may my belly not swell, was La Tenrirua. Also he himself was trusted by the people of Bone to do whatever he liked with the land of Bone. ${ }^{78}$

Yet even before he had been king for three months, it happened that the Karaeng attacked Bone in the war about Islam. The Makasars built a fort at Cellu, and also the Karaeng built a fort at Palletté. Islamic faith was displayed for the people of Bone.

ArumPone said, 'Since, people, you trust me to do what I like with the land of Bone, you raised the umbrella (over me). The Karaeng is displaying to us something good, and so it is good that we share the Islamic faith. For there was a former agreement of ours with the Karaeng that should one discover anything good and shining bright, ${ }^{79}$ then one would show it. This Karaeng says, "I say it is good and shining bright for me (the Karaeng) to hold to the religion of the Prophet." Moreover the Karaeng says, "If you accept my instruction, we will both be great, just Gowa and Bone, and together equally we will serve the One God."' ArumPone also went on to say, 'If, friends, you do not accept the good instructions of the Karaeng, he is in earnest and we will be forced to acknowledge him and be slaves in his name..$^{80}$ If you accept the good instruction of the Karaeng, he will relieve us of instruction on another occasion in future. You think I am not willing to fight and be killed. Indeed after this I will fight if he reneges on his undertaking to me.'

78 Literally, to make it lie on its front or its back.

79 In what follows, this is used metaphorically to mean true belief. True light is a familiar metaphor.

80 That is, as well as being subject to him by reason of defeat. 
The people of Bone were united in refusing to give assent to the Islamic faith.

ArumPone was silent since ArumPone felt that the people of Bone were moving in other directions. ArumPone just took himself and went to Pattiro. Only his personal staff followed him. When he came to Pattiro, he talked again with the people of Pattiro, yet again they did not want to follow the Islamic faith. Our lord was silent and went up to the palace and kept to himself. Only his personal associates went with him. His children and his wife, he forced them all up into the palace.

When ArumPone had been put aside and gone to Pattiro, the people of Bone gathered together. They agreed together that ArumPone should be driven out. The people of Bone sent (an envoy) to go to Pattiro, and To Alaung was the name of (the man) who was sent. When To Alaung arrived in Pattiro, he went up to the palace. He said, 'To Alaung, sir. This is what the common people of Bone have sent me (to say), sir. It is not that we do not want you, but you do not want us. An enemy has come upon your servants in Bone, and you have left them.'

Our lord said, 'O, To Alaung, I deny that I do not want the people of Bone, I only scoff at the people of Bone in that I show them what is good and shining bright. I really want to lead you to the light. You, people, do not want (to come). But you are fixed, friends, in your darkness of mind. Yet I go to the light which the One God makes to burn in the Prophet.'

After To Alaung spoke, he returned to Bone. Again the people of Bone agreed together and they made the Arung Timurung king in Bone, since he was a child of Matinroé riAddénénna. He was called, may my belly not swell, La Tenripale' as his personal name, To Akkempéang as his teknonym. When he had passed on, he was called Matinroé riTallo'. When he was king, he made the people of Bone fight in the war about Islam.

After his departure, To Alaung went to Bone, and our lord also sent (an envoy) to go to the Karaeng there at Palletté. When his envoy arrived at Palletté, the Karaeng also sent (an envoy) to go to Pattiro. Karaeng Pettung was sent. When Karaeng Pettung arrived at Pattiro, our lord was besieged by the people of Pattiro and the people of the hills. He went to meet them and ran amuck, and he repulsed all the hill (people) and the people of Pattiro and finished them off in the hills at Maroanging. 
After that our lord crossed to Palletté to meet the Karaeng. Only Karaeng Pettung occupied Pattiro. When our lord reached the Karaeng, the Karaeng said, 'It is good, friend, that you come here. For I ask you where all your private property is. Although you are not king of Bone, you still have property. Although I acknowledge you own Bone, that has changed hands.'

Our lord said, 'My personal property consists of Palakka and Pattiro and AwamPoné. As for Mario-Riwawo, that is also the personal property of my wife.'

The Karaeng said, 'Make the confession of faith and on that day also the sum total of what you own accepts the confession of faith. Bone will not enslave you, Gowa will not enslave you.'

Our lord said, 'It is only about the confession of faith, Karaeng, that I have come here.'

After that then the Karaeng said, 'I know that you own Palletté. But my standard has been set up and I claim it as my property, but since Palletté is indeed my property, I give (it) to you.'

After that our lord was given by the Karaeng a velvet jacket braided with pure gold weighing 1 kati.

Our lord said, 'If, Karaeng, you give me (this) so that I will not accompany the people of Bone in opposing you, I do not want to take it.'

The Karaeng said, 'You know, father of my daughter-in-law, that it was the custom of the people of former times, if they met a member of their family, that there was also made as an expression of the meeting an exchange of one slice of areca nut and one leaf of sirih.'

Our lord said, 'I will own that (jacket), Karaeng, since such is your word.'

Following that then our lord and the Karaeng made an agreement. (There was) our lord Matinroé riBantaéng, the Karaeng of Gowa who introduced Islam and the Karaeng of Tallo who introduced Islam. This was their agreement. The Karaeng said, 'As we (all here) make witness before the One God, may there be no more of our family ${ }^{81}$ to be king in

81 The first 'we' is inclusive in contrast to the 'our', which is exclusive and therefore refers to the families of the Karaéngs of Gowa and Tallo. 
Gowa and in Tallo if you do not possess your property, if you are treated poorly by your fellow people. If there is any evil affecting you, open your door and I will come in to your evil.'

Matinroé riBantaéng also said, 'O, Karaeng, may my paddy sheaves not thresh properly, may my total (harvest) not be complete, may mice not be kept clear from my (storage) pile, if there is anything affecting the land of Gowa. Although I swim on only one trunk of bamboo, I will come to a crisis ${ }^{82}$ and to your difficulty, Karaeng. This will apply to your descendants and also to my descendants, if only (your) word to us is not broken, to us who are little people.'

Such was the agreement of Matinroé riBantaéng and the Karaeng. After our lord and the Karaeng had made the treaty, they returned again to Pattiro. Five nights after the Karaeng and our lord Matinroé riBantaéng had made the treaty, they turned their attention to Bone and there was a war against Islam. The people of Bone rendered homage and were made to take the confession of faith, and the Karaeng returned to his territory.

As soon as the Karaeng had gone away, Matinroé riBantaéng was ordered to leave by the people of Bone. He went out to Makassar and was a pupi ${ }^{83}$ to Dato' (ri) Bandang. Then Matinroé riBantaéng was given a foreign name ${ }^{84}$ by Dato' (ri)Bandang and Adam was the foreign name of Matinroé riBantaéng. He stayed with Dato' (ri)Bandang for a long time. Then he was given the choice of where to live by the Karaeng and he chose to live at Bantaeng. Hence he was taken there, and Matinroé riBantaéng stayed there, and there he reached his span of years, and he was called Matinroé riBantaéng.

\section{2}

Matinroé riBantaéng was driven out and he was first cousin to Matinroé riTallo'. After Matinroé riBantaéng had been driven out, the people of Bone agreed to make Arung Timurung king, since he was the child of Matinroé riAddénénna by the queen of Timurung. Then there was ArumPone, may my belly not swell, called La Tenripale', To Akkempéang his title.

82 Literally, to a corner.

83 Literally, a child.

84 That is, in this context, a Muslim name. 
When he was ruling, he made the people of Bone return to the war about Islam. Bone was burned and the people of Bone submitted, its thousandfold ransom was not taken, its fine was not demanded and it was not plundered either. The people of Bone rendered homage and were made to accept the confession of faith and that was the end of the matter, for they all settled down as vassals (to Gowa). After the people of Bone were made to accept the confession of faith, all the vassals (of Bone) were made to accept the confession of faith. When the Karaeng had again gone back to his territory, Arung Timurung ruled in Bone. He passed on and was called Matinroé riTallo'.

Matinroé riTallo' was one of two siblings. His younger sister was called, may my belly not swell, Wé Tenrijello', and she was entitled Makkalaru'é. Makkalaru'é married the king of Sumali, called La Pancai. They were the parents of (a child) who was called La Maddaremmeng, Salih was his foreign name. He was made king in Timurung. Then Pattiro was taken, and Makkalaru'é was also queen of Pattiro. One of the other younger brothers of La Maddaremmeng, may my belly not swell, was called Tenriampareng. He was king of Cellu. One of the other younger brothers was called La Tenriaji, To Senrima was his teknonym. He was made king in AwamPoné. He also was called Pawélaié riSiang $<$ He who passed away in Siang>.

She who was called, may my belly not swell, Wé Tenrisui married La Pottobune', the king of Tana-Tengnga. They were the parents of (a child) who was called Da Unru', may my belly not swell, (and one) who was called La Tenritatta, To Unru' being his teknonym, and who had no children, and (one) Da Tenrigerra, who also died without family, and (one) Da Ompo', who had no children, and (one) Da Éba, and (one) who was called, may my belly not swell, Wé Pappolobonga, Da Umpi being her teknonym. She was called Maddanrengngé <the Maddanreng $>$.

One year after the people of Bone made the confession of faith, (ArumPone) went out to Makassar and met Dato' riBandang and he was called Abdullah, as the foreign name of ArumPone. As king he was good-hearted. He was also said to be a person who enjoyed entertainment, he was also said to have been very interested in agriculture. 
He married the child of Matinroé riSidénréng who was entitled Kaunangngé. Their child was entitled Dabe'. Dabe' was the bride of the child of the Karaeng of Gowa, who introduced Islam. Daéng Mattola was the name of the Karaeng's child who took Dabe' as a bride. Yet before her menarche, she died. It happened that ArumPone had no more children of equivalent status.

As king he went and returned from the Karaeng and it was a very long interval if there were three years between visits.

(Once) when it was time for him to visit Makassar, he arrived to visit Makassar. There illness struck him and illness carried him off. Since there in Tallo he is buried, he was called Matinroé riTallo'. There were 20 years of rule and he passed away.

\section{3}

Matinroé riTallo' had as his sister's child, Matinroé riBukaka. When Matinroé riTallo' passed on, his sister's child succeeded to rule in Bone, since that had been bequeathed (to him). La Maddaremmeng, may my belly not swell, was his personal name, Salih his foreign name. When he passed on, he was called Matinroé riBukaka.

When he was ruling, he made a white umbrella.

He married in Wajo Hatija, Da Senrima was her teknonym, the child of the Arung Matoa of Wajo, who was entitled To Ala'é. ArumPone had just one child, who was called Pakkoko'é, To Akkonéng his title.

Also when he was ruling, he extended the wall of Bone, extending it to the east and extending it to the south.

He was also said to be firm in practising religion. Also he cared strongly about it and was angry at those who did not care strongly about it. He ordered his parent to care strongly about it, but Makkalaru'é replied and said, 'I am not able (to do it), do not give (me) orders.' 
He was angry at his parent and attacked Pattiro and sacked it. Makkalaru'é fled away to the Karaeng. The Karaeng of Gowa ordered ArumPone to be mindful. Bone was attacked by the Karaeng, and was conquered. ArumPone fled up to Cempu, he was followed, imprisoned, and carried away to Makassar. He was put in Siang.

Fifteen years he was king, and the people of Bone fled. ${ }^{85}$ When he passed on he was called Matinroé riBukaka.

When Bone was deserted by Matinroé riBukaka, the brother of Matinroé riBukaka who was called To Senrima still remained in Bone. Yet again for another time Bone was attacked by the Karaeng and conquered, and prisoners were taken. That was called the Pasémpe' defeat, since the people of Bone went up to Pasémpe' to fight. To Senrima was also carried away and there he died. Then he was called Pawélaié riSiang.

Matinroé riBukaka just stayed in Siang together with the people of Bone who had been taken prisoner. That is the limit of what is told of Matinroé riBukaka though more is told in the place where he was living, but he was no longer king of Bone.

It reached the stage when there was only an official, whom the Karaeng set up to live in Bone. To Bala was the name of the person who acted as official in Bone. Then it was clear that the people in Bone had become slaves to the Makasars.

After 17 years of To Bala being the official, he supported the people of Bone (in revolt) and again the people of Bone were conquered by the Makasars, and To Bala was struck down. This was pronounced the To Bala defeat.

85 Presumably, this refers to the defeat at the hands of Gowa. The text is clear enough, but it is tempting to suggest an emendation to the effect that it was the ArumPone who fled. 
The Matinroé riBontoala' crossed to Butung. This is said to have ended the enslavement of the land of Bone by the Makasars.

When To Bala died, Arung Amali in turn became official in Bone. After seven years of Arung Amali, he took the people of Bone off to Butung. There on Butung were the people of Bone, and there also was Matinroé riBontoala' together with the Dutch. Then the people of Bone were captured by Matinroé riBontoala', and Karaeng Bontomarannu and all the Makasars were captured as well, everything that there was on Butung. The end. 
This text is taken from The Bugis Chronicle of Bone, translated and edited by Campbell Macknight, Mukhlis Paeni and Muhlis Hadrawi, published 2020 by ANU Press, The Australian National University, Canberra, Australia.

doi.org/10.22459/BCB.2020.05 